\title{
Gambaran berat jenis urin pada pasien tuberkulosis paru dewasa di Rsup Prof. Dr. R. D. Kandou Manado
}

\author{
${ }^{1}$ Aldira B. Pratama \\ ${ }^{2}$ Arthur E. Mongan \\ ${ }^{2}$ Mayer F. Wowor
${ }^{1}$ Kandidat Skripsi Fakultas Kedokteran Universitas Sam Ratulangi Manado
${ }^{2}$ Bagian Patologi Klinik Fakultas Kedokteran
Universitas Sam Ratulangi Manado \\ Email: aldira_bayu@yahoo.com
}

\begin{abstract}
Tuberculosis (TB) is a chronic infectious disease caused by Mycobacterium Tuberculosis. Drugs that given to the TB patients such as isoniazid, pyrazinamide, ethambutol, streptomycin, and rifampicin. Rifampicin and streptomycin can damage the kidneys and can changes in the urine specific gravity. This study aims to describe the specific gravity of urine in adult pulmonary TB patients in the department of Prof. Dr. R. D. Kandou Manado. This research uses descriptive observational method by means of random consecutive sampling to obtain data on the weight of the urine in adult pulmonary TB patients conducted in October-November 2016 in the department Prof. Dr. R. D. Kandou Manado. The sample used is a urine sample from pulmonary TB patient with inclusion criteria. The result of urine specific gravity test that obtained from 30 patients with pulmonary tuberculosis, 27 patients (90\%) with the results of 1010-1025, 1 patient $(3.33 \%)$ with the results of the urine specific gravity $\leq 1.005$, and 2 patients with the results of the urine specific gravity $\geq 1030$. outpatients have an average urine specific gravity higher than inpatients. Overview urine specific gravity in this study largely still in the normal range.
\end{abstract}

Keywords: pulmonary tuberculosis, Urinalysis, urine specific gravity

\begin{abstract}
Abstrak: Tuberkulosis (TB) adalah suatu penyakit infeksi kronik yang disebabkan oleh Mycobacterium tuberculosis. Obat yang diberikan pada pasien TB meliputi isoniazid, pirazinamid, etambutol, streptomisin, dan rifampisin. Rifampisin dan streptomisin dapat merusak ginjal dan dapat menyebabkan perubahan berat jenis urin. Penelitian ini bertujuan untuk mengetahui gambaran berat jenis urin pada pasien TB paru dewasa di RSUP Prof. Dr. R. D. Kandou Manado. Penelitian ini menggunakan metode deskriptif observasional dengan cara random consecutive sampling untuk mendapatkan data tentang berat jenis urin pada pasien TB paru dewasa yang dilakukan pada oktober-november 2016 di RSUP. Prof. Dr. R. D. Kandou Manado. Sampel yang digunakan adalah sampel urin sewaktu pasien TB paru yang memenuhi kriteria yang telah ditentukan. Hasil pemeriksaan berat jenis urin yang didapatkan dari 30 pasien TB paru, 27 pasien (90\%) dengan hasil 1.010-1.025, 1 pasien $(3,33 \%)$ dengan hasil berat jenis urin $\leq 1.005$, dan 2 pasien dengan hasil berat jenis urin $\geq 1.030$. pasien rawat jalan mempunyai rerata berat jenis urin lebih tinggi daripada pasien rawat inap. Gambaran berat jenis urin pada penelitian ini sebagian besar masih pada rentang normal.
\end{abstract}

Kata kunci: tuberkulosis paru, urinalisis, pemeriksaan berat jenis urin

Tuberkulosis merupakan suatu penyakit infeksi kronik yang sudah sangat lama dikenal. Tuberkulosis adalah suatu penyakit yang disebabkan oleh Mycobacterium 
tuberculosis. Tuberkulosis dapat ditularkan melalui inhalasi yang mengandung droplet nuclei, khususnya yang didapat dari penderita tuberkulosis paru. ${ }^{1}$

Tuberkulosis merupakan masalah kesehatan global. Pada tahun 2014 menurut Global Tuberculosis Control terdapat sekitar 9.6 juta kasus tuberkulosis baru, 5.4 juta kasus pada pria, 3.2 juta kasus pada wanita, dan 1 juta kasus pada anak-anak. Angka kematian akibat tuberkulosis masih tinggi yaitu 1.5 juta kematian, 890.000 pada pria, 480.000 pada wanita, dan 140.000 pada anak-anak. Angka kejadian di Indonesia menurut WHO (World Health Organitation) sendiri masih tinggi yaitu 1 juta kasus dari 9.6 juta kasus baru secara global dan terdapat 100.000 kematian akibat tuberkulosis. ${ }^{2}$

Prevalensi tuberkulosis di Indonesia menurut hasil Riskesdas tahun 2013, berdasarkan diagnosis terdapat sebesar $0.4 \%$ kasus dari jumlah penduduk. Berdasarkan provinsi, prevalensi tuberkulosis paru tertinggi berada di Jawa Barat sebesar $0.7 \%$, DKI Jakarta sebesar 0.6\% dan Papua sebesar 0.6\%. Sedangkan Provinsi Riau, Lampung, dan Bali merupakan provinsi dengan prevalensi tuberkulosis terendah yaitu masing-masing sebesar $0.1 \% .^{3}$

Urinalisis adalah pemeriksaan fisik, kimia, dan mikroskopik pada urin yang bertujuan untuk menegakkan suatu diagnosis penyakit. $^{4}$ Urinalisis telah dilakukan sejak 6000 tahun yang lalu dan menjadi pemeriksaan laboratorium pertama. $^{5}$ Urinalisis melibatkan sejumlah pemeriksaan untuk mendeteksi dan mengukur bermacam komponen yang melewati urin. Salah satu pemeriksaan yang ada dalam urinalisis adalah pemeriksaan berat jenis urin. ${ }^{4}$

Berat jenis urin adalah ukuran konsentrasi solut dalam urin. Berat jenis urin memberi informasi tentang kemampuan ginjal dalam mengonsentrasikan urin. Nilai normal berat jenis urin adalah $1.005-1.030 .^{6}$ Komponen yang dapat mempengaruhi berat jenis urin antara lain molekul berukuran besar seperti protein dan glukosa. ${ }^{7}$

Pemeriksaan berat jenis urin merupakan suatu pemeriksaan yang sering dilakukan dalam urinalisis. ${ }^{6}$ Penurunan berat jenis urin dapat terjadi pada penderita diabetes insipidus, berbagai kelainan ginjal, pielonefritis, dan glomerulonefritis. Peningkatan berat jenis urin dapat terjadi pada penderita dengan dehidrasi, gagal jantung kongestif, insufisiensi adrenal, dan penyakit hati. ${ }^{4}$

Pengobatan pada pasien tuberkulosis menggunakan obat anti tuberkulosis yang terdiri dari rifampisin, isoniazid, etambutol, pirazinamid, dan streptomisin. Kemampuan rifampisin meningkatkan respon imun dan pada saat tertentu dapat menyebabkan kerusakan sel. Rifampisin dan streptomisin merupakan obat yang tergolong sebagai nefrotoksik, yang berarti dapat merusak ginjal. ${ }^{8,9}$

Bila kerusakan terjadi pada bagian tubulus ginjal akan mengakibatkan gangguan reabsorpsi zat. ${ }^{10}$ Kerusakan ini akan berdampak pada berat jenis urin. Berdasarkan hal diatas, penulis tertarik untuk mengetahui gambaran berat jenis urin pada pasien tuberkulosis di RSUP. Prof. Dr. R. D. Kandou Manado.

\section{METODE PENELITIAN}

Penelitian ini merupakan studi deskriptif cross sectional. Penelitian ini dilaksanakan di poliklinik paru dan instalasi rawat inap bagian penyakit dalam RSUP. Prof. Dr. R. D. Kandou Manado selama bulan oktober sampai november 2016. Sampel penelitian ini adalah sampel urin sewaktu dari semua pasien tuberkulosis paru dewasa dalam kurun waktu dan kriteria yang telah ditentukan dengan cara non-probability sampling jenis consecutive sampling.

\section{HASIL PENELITIAN DAN BAHASAN}

Sesuai hasil penelitian di RSUP Prof. Dr. R. D. Kandou Manado pada bulan Oktober 2016 - November 2016 terdapat 30 pasien yang memenuhi kriteria inklusi. 
Tabel 1. Distribusi sampel berdasarkan usia

\begin{tabular}{ccc}
\hline Usia & Jumlah & $\%$ \\
\hline 18-25 Tahun & 4 & $13,3 \%$ \\
26-35 Tahun & 4 & $13,3 \%$ \\
36-45 Tahun & 8 & $26,7 \%$ \\
46-55 Tahun & 6 & $20,0 \%$ \\
56-65 Tahun & 6 & $20,0 \%$ \\
66-75 Tahun & 2 & $6,7 \%$ \\
\hline Total & 30 & $100,0 \%$ \\
\hline
\end{tabular}

Berdasarkan Tabel 1, dapat dilihat bahwa pada kelompok usia 36-45 tahun merupakan kelompok usia terbanyak $(26,7 \%)$ yang menderita tuberkulosis. Hasil penelitian ini sama dengan penelitian oleh Rukmini dan Chatarina pada bulan maret 2010 yang menunjukkan bahwa penderita tuberkulosis kebanyakan pada usia 35-54 tahun. ${ }^{11}$ Penelitian dari Xinyu et al pada tahun 2010 dari 3.759 pasien tuberculosis paru menunjukkan pada usia 25-44 tahun (1.683 pasien) merupakan usia rentan tuberkulosis. $^{12}$ Data dari Kementerian Kesehatan RI pada tahun 2014 menampilkan hasil yang sedikit berbeda dengan hasil dari penelitian ini, yaitu bahwa tuberculosis terbanyak ditemukan pada kelompok usia 25 - 34 tahun $(20,76 \%)$ kemudian diikuti oleh kelompok usia 35-44 tahun $(19,24 \%){ }^{3}$ Berdasarkan hasil tersebut, menunjukan bahwa kejadian tuberkulosis lebih banyak pada usia produktif.

Tabel 2. Distribusi jenis kelamin

\begin{tabular}{lcc}
\hline Jenis Kelamin & Jumlah & $\%$ \\
\hline Laki-laki & 20 & $66,7 \%$ \\
Perempuan & 10 & $33,3 \%$ \\
\hline \multicolumn{1}{c}{ Total } & 30 & $100,0 \%$ \\
\hline
\end{tabular}

Pada Tabel 2 didapatkan 20 orang lakilaki $(66.67 \%)$ dan 10 orang perempuan (33.33\%)Data dari Global Tuberculosis Control pada tahun 2014 menunjukan hal yang sama, yaitu pria lebih banyak terkena tuberkulosis dari pada wanita dengan jumlah 5.4 juta kasus pada pria dan 3.2 juta kasus pada wanita. ${ }^{2}$ Penelitian dari Eni et al pada tahun 2012 juga menunjukkan bahwa laki-laki lebih rentan terkena tuberkulosis
(70.8\% lebih banyak). ${ }^{13}$ Berdasarkan hasil tersebut, menunjukan bahwa jenis kelamin laki-laki lebih beresiko terkena tuberkulosis.

Tabel 3. Distribusi jenis kasus TB

\begin{tabular}{lrrr}
\hline \multirow{2}{*}{$\begin{array}{c}\text { Jenis Kasus } \\
\text { TB }\end{array}$} & \multicolumn{1}{c}{$\begin{array}{c}\text { Rawat } \\
\text { Inap }\end{array}$} & $\begin{array}{c}\text { Rawat } \\
\text { Jalan }\end{array}$ & \multicolumn{1}{c}{ Total } \\
\cline { 2 - 4 } \multicolumn{1}{c}{ Jumlah } & Jumlah & Jumlah \\
\hline Baru & 1 & 12 & 13 \\
Gagal terapi & 0 & 1 & 1 \\
Putus Obat & 3 & 5 & 8 \\
Relaps & 2 & 6 & 8 \\
\hline Total & 6 & 24 & 30 \\
\hline
\end{tabular}

Pada Tabel 3, didapatkan jenis kasus pasien tuberkulosis paru terbanyak adalah pasien tuberkulosis paru baru. Hasil dari penelitian ini serupa dengan hasil penelitian yang dilakukan oleh Eni et al yaitu penderita TB paru baru merupakan penderita terbanyak yang didapat $(91,7 \%)^{13}$

Tabel 4. Distribusi penyakit penyerta TB

\begin{tabular}{lcc}
\hline Penyakit Penyerta & Jumlah & $\%$ \\
\hline Hipertensi & 4 & $20 \%$ \\
Asam urat & 5 & $25 \%$ \\
Diabetes melitus & 5 & $25 \%$ \\
Gangguan ginjal & 6 & $30 \%$ \\
\hline
\end{tabular}

Pada Tabel 4, didapatkan 4 orang pasien $(13 \%)$ dengan penyakit penyerta hipertensi, 5 orang pasien $(17 \%)$ dengan penyakit penyerta diabetes melitus, 5 orang pasien $(17 \%)$ dengan asam urat tinggi, dan 6 orang pasien (20\%) dengan penyakit ginjal. Penelitian serupa pernah dilakukan oleh Irwanto di RSUP. Prof. Dr. R. D. Kandou Manado dengan hasil penyakit komorbid hipertensi sebanyak 13,3\%, dan diabetes melitus sebanyak $13.3 \% .^{14}$ Penelitian dari Wijaya mengatakan penderita diabetes melitus memiliki resiko 2 hingga 3 kali lebih besar untuk mengidap penyakit tuberkulosis paru. ${ }^{15}$

Pada Tabel 5, didapatkan 24 orang dengan jenis OAT kategori 1 dan 6 orang dengan jenis OAT kategori 2. Hasil didapatkan OAT kategori 1 diberikan 
terbanyak karena pasien dengan TB paru baru merupakan pasien terbanyak pada penelitian ini, yaitu 12 orang pasien $(38 \%)$ dan terdapat pasien TB paru relaps serta putus obat yang diberikan OAT kategori 1.

Tabel 5. Distribusi jenis OAT

\begin{tabular}{lccc} 
Jenis OAT & $\begin{array}{c}\text { Rawat } \\
\text { Inap }\end{array}$ & $\begin{array}{c}\text { Rawat } \\
\text { Jalan }\end{array}$ & Total \\
\cline { 2 - 4 } & Jumlah & Jumlah & Jumlah \\
\hline Kategori 1 & 4 & 20 & 24 \\
kategori 2 & 2 & 4 & 6 \\
Total & 6 & 24 & 30 \\
\hline
\end{tabular}

Dari Tabel 6, 7, dan 8 didapatkan hasil berat jenis urin sebagian besar masih dalam rentang normal.

Tabel 6. Distribusi berat jenis urin

\begin{tabular}{ccc}
\hline \multirow{3}{*}{$\begin{array}{c}\text { Berat Jenis } \\
\text { Urin }\end{array}$} & $\begin{array}{c}\text { Tanpa } \\
\text { Penyakit } \\
\text { Penyerta }\end{array}$ & $\begin{array}{c}\text { Dengan } \\
\text { Penyakit } \\
\text { Penyerta }\end{array}$ \\
\cline { 2 - 3 } & Jumlah & Jumlah \\
\hline$\leq 1.005$ & 1 & 0 \\
$1.010-1.025$ & 14 & 13 \\
$\geq 1.030$ & 1 & 1 \\
\hline
\end{tabular}

Tabel 7. Distribusi berat jenis urin berdasarkan kategori OAT

\begin{tabular}{lccc}
\hline & \multicolumn{3}{c}{ Berat Jenis Urin } \\
\cline { 2 - 4 } Jenis OAT & $\leq 1.005$ & $1.010-$ & $\geq 1.030$ \\
\hline Kategori 1 & 0 & 1.025 & \\
Kategori 2 & 1 & 5 & 0 \\
\hline
\end{tabular}

Tabel 8. Distribusi berat jenis urin berdasarkan lama pengobatan

\begin{tabular}{lccc}
\hline & \multicolumn{4}{c}{ Berat jenis urin } \\
\cline { 2 - 4 } \multicolumn{1}{c}{ Lama } & \multicolumn{3}{c}{1.010} \\
& $\leq 1.005$ & - & $\geq 1.030$ \\
& & 1.025 & \\
\hline$<$ 1 bulan & 0 & 12 & 1 \\
1-2 bulan & 1 & 7 & 0 \\
3-6 bulan & 1 & 5 & 0 \\
$>$ 6bulan & 1 & 3 & 1 \\
\hline
\end{tabular}

Pada Tabel 9 didapatkan rerata berat jenis urin pada pasien rawat jalan lebih tinggi dari pada rerata berat jenis urin pasien rawat inap. Berdasarkan teori, berat jenis urin pada pasien dapat dipengaruhi oleh penyakit-penyakit penyerta seperti hipertensi, penyakit ginjal dan diabetes melitus, aktivitas pasien, serta dapat juga dipengaruhi oleh efek samping dari OAT.

Tabel 9. Distribusi berat jenis urin berdasarkan pelayanan medis

\begin{tabular}{|c|c|c|c|}
\hline \multirow{5}{*}{$\begin{array}{c}\text { Jenis } \\
\text { Pelayanan } \\
\text { Medis }\end{array}$} & Tanpa & & \multirow{4}{*}{ Total } \\
\hline & Penyaki & Dengan & \\
\hline & l & Penyakı & \\
\hline & $\begin{array}{c}\text { Penyert } \\
\text { a }\end{array}$ & Penyerta & \\
\hline & Rerata & Rerata & $\begin{array}{c}\text { Rerat } \\
\text { a }\end{array}$ \\
\hline Rawat inap & 1.012 & 1.016 & 1.015 \\
\hline Rawat Jalan & 1.016 & 1.017 & 1.016 \\
\hline
\end{tabular}

Ginjal merupakan organ yang berperan dalam homeostasis dan pemekatan urin. Pemekatan urin di ginjal terjadi di tubulus dan medulla ginjal. Pada seseorang dengan penyakit ginjal, dapat terjadi penurunan atau kehilangan kemampuan tubulus ginjal dalam mekanisme pemekatan urin. Kehilangan kemampuan ini dapat menyebabkan turunnya hasil dari berat jenis urin dan bila kerusakan sudah parah maka berat jenis urin akan berada di nilai $1.010 .5,16$

Diabetes melitus merupakan penyakit yang ditandai dengan peningkatan kadar glukosa dalam darah. Pada pasien dengan diabetes melitus dapat terjadi kelainan metabolisme lemak karena kurangnya efek insulin dalam menggunakan glukosa dan menyebabkan pembentukan asam keto yang berlebihan. Penguraian asam-asam keto ini menyebabkan peningkatan konsentrasi $\mathrm{H}^{+}$plasma dan disebut sebagai asidosis metabolik. Ginjal mempunyai mekanisme kompensasi untuk asidosis metabolic, yaitu dengan mengekskresikan $\mathrm{H}^{+}$. ekskresi pada urin ini meningkatkan hasil dari berat jenis urin. ${ }^{16}$

Pasien tuberkulosis menerima pengobatan dengan menggunakan OAT. Beberapa OAT mempunyai efek samping nefrotoksik pada tubuh seperti rifampisin 
dan streptomisin. Dalam beberapa penelitian berpendapat bahwa terjadi reaksi hipersensitifitas tipe 2 dan 3 yang terjadi akibat paparan dari rifampisin. Rifampisin membentuk kompleks antibodi di pembuluh darah ginjal yang dapat menyebabkan endoteliosis glomerular dan daerah intertisial. Nekrosis tubulus akut dapat terjadi karena penyempitan pembuluh darah dan iskemia tubulus yang disebabkan oleh penumpukan kompleks antibodi di pembuluh darah, serta nefritis interstisial akut dapat terjadi karena penumpukan kompleks antibodi di area interstisial. ${ }^{17}$ Kerusakan tubulus akan menurunkan fungsi dari ginjal. Kerusakan yang disebabkan oleh rifampisin mulai terjadi pada hari ke 13 setelah konsumsi. ${ }^{18}$ Pada orang dengan usia lanjut lebih rentan terkena gangguan ginjal yang disebabkan oleh obat karena kemampuan ginjal dalam penyembuhan sudah lemah. ${ }^{17}$ Streptomisin merupakan suatu antibiotik aminoglikosida. Aminoglikosida merupakan suatu polikation yang jika berjumlah banyak dapat menyebabkan efek nefrotoksik. Aminoglikosida mempunyai berat molekul 500 dalton dan dapat berikatan pada protein. Pengeliminasian aminoglikosida terjadi di filtrasi glomerulus. Manifestasi awal dari nefrotoksik akibat aminoglikosida berupa bertambahnya jumlah urin yang dihasilkan dan terdapatnya enzimuria. Perjalanan aminoglikosida menjadi nefrotoksik dari terikatnya aminoglikosida dengan asam fosfoinositida bermuatan negative yang pada tubulus proksimal yang merupakan komponen dari brush border. Penumpukan dari aminoglikosida inilah yang menyebabkan kerusakan di tubulus. Kerusakan yang terjadi pada tubulus ginjal berakibat pada hasil berat jenis urin. ${ }^{8}$

\section{SIMPULAN}

Berdasarkan hasil penelitian yang dilakukan di RSUP. Prof. Dr. R. D. Kandou Manado, dapat disimpulkan bahwa hasil pemeriksaan berat jenis urin sebagian besar masih normal dengan rerata berat jenis urin pada pasien rawat jalan lebih tinggi dari rerata berat jenis urin pasien rawat inap.

\section{DAFTAR PUSTAKA}

1. Amin Z, Bahar A. Tuberkulosis Paru. Dalam: Setiati S, Alwi I, Sudoyo AW, Simadibrata KM, Setiyohadi B, Syam AF, editor. Buku Ajar Ilmu Penyakit Dalam. Edisi ke-6. Jakarta: InternaPublishing; 2014. h. 863-78.

2. World Health Organization. Global Tuberculosis Report 2016. 2016.

3. Kementerian Kesehatan RI. Profil Kesehatan Indonesia tahun 2014. 2015.

4. McPherson AR, Ben-Ezra J, Zhao S. Basic Examination of Urin. In: McPherson RA, Pincus MR, (editors). Henry's Clinical Diagnosis and Management by Laboratory Methods. $22^{\text {nd }}$ ed. philadelphia, PA, USA: Elsevier Saunder; 2011. p.446.

5. Murphy TE. The Urinalysis-Inexpensive and Informative. J Insure Med. 2004. 36:320-6

6. Ghadban R, Staros E, Lin J. Specific Gravity. Medscape Emedicine. 2014.[Cited 2016 sep 11]. Available from:http://emedicine.medscape.com/ article/2090711-overview\#a2.

7. Florescu MC. Approach to Renal Diagnostic Testing. In: Lerma EV, Rosner M, editors. Clinical Decisions in Nephrology, Hypertension and Kidney Transplantation. New York: Springer Science \& Business Media;2013. p. 19.

8. Beebe A, Seaworth B, Patil N. RifampicinInduced nephrotoxicity in a tuberculosis patient. J Clin Tuber Microbiol Dis. 2015;4:13-5

9. Malhotra KK. Treatment of tuberculosis in chronic renal failure, maintenance dialysis and renal transplant. Indian $\mathbf{J}$ Nephrol. 2003;13:69-71.

10.Walsh SB, Unwin RJ. Renal Tubular Disorders. CME Renal Med. 2012. 12(5):.476-9.

11.Rukmini, Chatarina UW. Faktor-faktor yang Berpengaruh Terhadap Kejadian TB Paru Dewasa di Indonesia (Analisis Data Riset Kesehatan Dasar Tahun 2010). Buletin Penelitian Sistem Kesehatan. 2010;14(4):320-31 
Pratama, Mongan, Wowor: Gambaran berat jenis...

12.Zhang X, Andersen AB, Lillebaek T, Zaza K, Thomsen VO, Ladefoged K, et al. Effect of Sex, Age, and Race on the Clinical Presentation of Tuberculosis: A 15-Year PopulationBased Study. Am J Trop Med Hyg. 2011;85(2) 285-90

13.Susilayanti EY, Medison I, Erkadius. Profil penderita penyakit Tuberkulosis paru BTA positif yang ditemukan di BP4 Lubuk Alung preiode Januari 2012-desember2012. Jurnal kesehatan Andalas. 2014;3(2):151-5

14. Kondo I, Wongkar M, Ongkowijaya J. Gambaran kadar asam urat pada penderita tuberkulosis paru yang menerima terapi obat anti tuberkulosis di RSUP Prof. Dr. R. D. Kandou Manado periode Juli 2014 -
Juni 2015. Jurnal e-clinic. 2016;4(1):344-8

15. Wijaya I. Tuberkulosis paru pada penderita diabetes melitus. CDK-229. 2015;42(6):412-7

16.Sherwood L. The Urinary System. In: Human physiology from cells to system. $\quad 8^{\text {th }}$ ed. Canada:Brooks/Cole;2013.p. 504-26

17.Chia HC, Yen FC, Vin CW, Chin CS, Chih HL, Jann YW, et al. Acute Kidney Injury Due to Antituberculosis Drugs: a Five Year Experience in an Aging Population. Biomed Central Infectious Disease. 2014;14:29

18.Singh NP, Ganguli A, Prakash A. DrugInduced Kidney Disease. JAPI. 2003;51:970-8. 